\title{
THE IMPACT OF CONSUMER ETHNOCENTRISM AND THE PATRIOTISM ON JUDGEMENT FOR SELECTED DOMESTIC PRODUCTS: THE CASE OF SLOVAKIA
}

\section{Čvirik, M.}

Marián Čvirik / University of Economics in Bratislava, Faculty of Commerce, Department of Marketing, Dolnozemská cesta 1, 85235 Bratislava, Slovakia. Email: marian.cvirik@euba.sk

\begin{abstract}
In this article, we focus on ethnocentrism applying to the theory of consumer behaviour while a relatively new concept of consumer ethnocentrism was created, which is under-studied in Slovakia. A patriotism indicates a second research issue. However, this concept is used in purchase and marketing conditions rarely. Based on these facts, we decided to contribute to a set of knowledge with new findings and broaden a knowledge base. This work's main aim is to research consumer ethnocentrism and patriotism impact on evaluation and preference of domestic products. The primary quantitative survey supports this study. The fundamental part of our survey is 628 respondents. We created partial goals which produce a foundation for the phrasing of survey questions and hypotheses. These were tested by a one-way ANOVA test. We used a model of linear regressive analysis for pinpointing direction and frequency effect. Results suggest a strong link between consumer ethnocentrism and patriotism. Based on these results, consumer ethnocentrism and patriotism can be marked as factors that positively influence a preference and evaluation of domestic products. But both concepts show themselves in different frequency in different product categories. Based on the results, we can state that it is necessary to explore both concepts when speaking of product categories. Results can be used in different fields (sociology, psychology and marketing) while representing a benefit for a theory and practice.

Implications for Central European audience: A knowledge used in different marketing campaigns supporting a domestic purchase can be established from the trade and marketing perspective. Noteworthy is also a discovery that the influence of concepts is not visible equally in each product categories. Results can be used by the Slovak republic government and domestic producers who are interested in an increase of competitiveness of domestic products. But also, it is for foreign producers who have an interest in expansion on the Slovak market.
\end{abstract}

Keywords: consumer ethnocentrism; patriotism; domestic products; Slovakia JEL Classification: M16, M31, Z10 


\section{Introduction}

Ethnocentrism and patriotism require considerable attention, mainly in internationalisation and globalisation, typically with attenuating ethnocentric tendencies. Ultimately, globalisation also leads to an increase in competition in the domestic and international market. A lot of foreign products on the domestic market can lead to increased consumption, which ultimately causes a decrease in the domestic economy due to the non-competitiveness of domestic products, a higher rate of unemployment, and other factors (Lutz et al., 2014).

Ethnocentrism has a significant position in sociology and psychology. However, the position of this concept is significant even in marketing. Mostly from the point of view of consumer behaviour. A new phenomenon, consumer ethnocentrism, was created as a synthesis of ethnocentrism and consumer behaviour. In Slovakia, research related to consumer ethnocentrism is rare (see Čvirik, 2018a, 2018b, 2018c; Lesáková, 2016; Lieskovská et al., 2013; Sedláková et al., 2007). Authors most often explore food products in the context of consumer ethnocentrism.

Initially, patriotism results from the sociological and political science field. However, the patriotism concept has a strong position even in politics, literature, and the international market (Rezvani et al., 2012). It is not known whether measurement of patriotism was implemented in Slovakia.

A strongly ethnocentric consumer is interested in domestic production to what extent they help his country's economy (e.g. lower unemployment, economic welfare growth, national budget growth, and others). We can say that an intensely patriotic consumer will prefer domestic production, though more likely from their country's love. While an ethnocentric consumer sees their country as a centre of everything and an aversion to foreign countries, a patriot does not have to share this aversion. This point can be taken for a significant difference.

It follows that consumer ethnocentrism and patriotism and their impact on the evaluation and preference of domestic products can be considered necessary not only in the marketing context but also in the national economy.

The Slovak government and various groups and domestic producers significantly try to support domestic products. Among the campaign can be included 'Kupujte slovenské!' ('Buy Slovak!'), 'Kvalita z našich regiónov!' ('Our Region Quality!') and others. Similar campaigns are created worldwide to increase demand from the domestic market; with it, they also influence these consumers' future behaviour (Alam et al., 2011).

The presented study explores consumer ethnocentrism and patriotism impact on evaluation and preferences to domestic products (as the case may be foreign products) in six product categories (dairy and meat products, fruit and vegetables, clothes, electronics and motor vehicles). Product categories have been chosen to achieve greater diversity (not just food). The paper's results extend the theory of consumer ethnocentrism and patriotism in Slovakia, thus contributing to its theoretical basis. From the practice point of view, the study brings new marketing opportunities for domestic and foreign companies operating in Slovakia. 


\section{Theoretical background and development of hypothesis and research questions}

For the first time, American psychologist William Graham Sumner (1906) presented the concept of ethnocentrism in his work named Folkways: A Study of the Sociological Importance of Usages, Manners, Customs, Mores, and Morals. Ethnocentrism, in general, was defined as 'the technical name for this view of things in which one's group (referred to as in-group) is the centre of everything, and all others (referred to as out-group) are scaled and rated with reference to it' (Sumner, 1906, 2007, p. 13). The author understands the ingroup as a social group connected by the same thinking, culture, and behaviour based on folklore (human habits). By definition, this in-group also serves as an assessment factor for other groups (out-groups). Thus, the in-group is looking for standard, and different features with each out-group, with the common features rated positively and the features of difference evaluated negatively, regardless of whether they are negative. The positive feature of the definition is its versatility, which creates the opportunity for various applications. The limits of definitions can be considered that it is only the name of the phenomenon.

Consumer ethnocentrism has been derived from this general concept. Shimp and Sharma (1987, p. 280) developed the definition of consumer ethnocentrism as 'the beliefs held by American consumers about the appropriateness, indeed morality, of purchasing foreignmade products. The authors clearly define in-group and out-group. In-group is considered domestic, and out-group is understood abroad. They consider consumer ethnocentrism as a belief that buying foreign products is wrong. Shimp and Sharma are also looking for why ethnocentric consumers are not interested in buying imported products. The main reasons for this are that buying foreign products is detrimental to the domestic economy, causing unemployment and acting unpatriotic. Due to the ethnocentric consumer's internal conviction, it is unacceptable to support the out-group (foreign) and harm the in-group (domestic). A positive of the definition is the clear indication of in-group and out-group groups and the definition of rejecting foreign products by ethnocentric consumers.

'From the perspective of ethnocentric consumers, purchasing imported products is wrong because, in their minds, it hurts the domestic economy, causes loss of jobs, and is unpatriotic; products from other countries (i.e. out-groups) are objects of contempt to highly ethnocentric consumers' (Shimp \& Sharma, 1987 p. 280). The author team Shimp and Sharma (1987) characterise the issue and the proposed possibilities of measuring consumer ethnocentrism based on the tool named Consumer Ethnocentrism Tendencies Scale (CETSCALE), including seventeen items. CETSCALE is the most popular scale usage in the context of consumer ethnocentrism in marketing. The level of consumer ethnocentrism is variable, and it is necessary to update this value regularly. It is also essential to update and modify CETSCALE for the object's specifications.

Based on the theoretical knowledge, we have created a research question - (RQ1): What is the consumer ethnocentrism level in Slovakia?

Patriotism emphasises national identity, representing a significant competitive advantage for domestic companies (Puncheva-Michelotti et al., 2014). Adorno et al. (1950) defined patriotism as a blind loyalty to the homeland. Sharma et al. (1995) define patriotism as an expression of love for the home country. Simultaneously, based on their research, a team of authors concluded that patriotism has a positive effect on consumer ethnocentrism. The 
same conclusions were reached by Han (1988) and Klein and Ettensoe (1999). Adorno et al. (1950) were the first to investigate the possibility of measuring patriotism. A tool called the Pseudopatriotism scale contains 14 statements to which a respondent replies with disagreement, the intensity of which is distributed over the Likert scale.

Based on the theoretical knowledge, we have created a research question - (RQ2): What is the patriotism level in Slovakia?

Sumner (1906) has already explored the relationship between patriotism and ethnocentrism. Several experts have studied the impact of patriotic behaviour on consumer ethnocentrism (Albarq \& Nik Mat, 2007; Balabanis et al., 2001; Sharma et al., 1995) who considered it to be one of the basic factors. Studies confirmed a positive relationship between consumer ethnocentrism and patriotism. However, Balabanis et al. (2001) point out that the relationship can change due to cultural differences.

Based on theoretical knowledge, we can formulate the hypothesis and research question. $(\mathrm{H} 1)$ : There is a relationship between consumer ethnocentrism and patriotism and the research question. (RQ3): What is the direction and magnitude of patriotism impact on consumer ethnocentrism?

Consumer ethnocentrism does not appear in all product categories (Balabanis \& Siamagka, 2017; Sharma et al., 1995). The interconnection of consumer ethnocentrism and the preference for domestic production has been the subject of several research types. 'The phenomenon of consumer preference for domestic products, or prejudice against imports, has been termed economic nationalism, cultural bias against imports, or consumer ethnocentrism' (Sharma et al., 1995, p. 26). According to Supphellen and Grønhaug (2003), highly ethnocentric consumers from Russia prefer domestic alternatives to foreign products. One of the most important criteria for evaluating products in the context of consumer ethnocentrism is the home product quality and price (Balabanis \& Siamagka, 2017; Ding, 2017; Ismail et al., 2012; Liu et al., 2006; Wang \& Chen, 2004). The basis, which is missing in many marketing studies, is the study of purchase intent (Khalid et al., 2018). Eagly and Chaiken defined (1993, p. 168) purchase intent as 'the person's motivation in the sense of his or her conscious plan to exert effort to carry out a behaviour'. Thus, from the perspective of the conative component of consumer behaviour, the consumer may be determined to make a purchase (purchase intention) or not buy the product (Brengman, 2002; Schiffman \& Kanuk, 2010). Thus, the most important factors to be examined in the context of the preference and evaluation of domestic products are price, quality and purchasing intent.

Based on theoretical knowledge, we have created a research question (RQ4): How do Slovak consumers evaluate selected domestic product categories?; and hypotheses - $(\mathrm{H} 2)$ : Consumers with higher consumer ethnocentrism levels have a more positive attitude towards domestic products and - $(\mathrm{H} 3)$ : Consumers with higher levels of patriotism have a more positive attitude towards domestic products.

\section{Methodology}

The study's main aim is to investigate the impacts of consumer ethnocentrism and patriotism on the judgment of domestic products.

We divided the primary goal into partial goals: 
- To measure consumer ethnocentrism in Slovakia (explored in RQ1).

- $\quad$ To measure patriotism in Slovakia (explored in RQ2).

- $\quad$ To verify a relationship between consumer ethnocentrism and patriotism (explored in $\mathrm{H} 1, \mathrm{RQ} 3)$.

- To examine the attitude of Slovak consumers towards domestic products. Measure the evaluation of selected product category of domestic production (explored in RQ4).

- Investigate the impact of consumer ethnocentrism and patriotism on the evaluation of domestic products (explored in $\mathrm{H} 2, \mathrm{H} 3$ ).

\subsection{Sampling and data collection procedures}

In the primary survey, we used a quantitative inquiry method to collect data. The basic population will be defined as Slovak consumers (consumer with Slovak nationality) older than 15 years. In most studies investigating consumer ethnocentrism or patriotism, the authors did not mention the age interfaces of respondents (they only mention segments - young and old). There are several reasons for determining the lower limit of our base population for 15 years. Still, the most important is that respondents (older than 15 years) have their own money and often decides on their own, without the involvement of parents about their purchases, as opposed to younger respondents (younger than 15-year-old) (Badzińska, 2011).

We used the non-probability sample - Quota sample. The reason for choosing this method is that many studies suggest a significant impact of demographic factors on consumer ethnocentrism, the rate of patriotism, and the preferences and evaluation of domestic and foreign products.

Based on the scientific studies as the most important demographic have been identified variables - gender (Bruning, 1997; Čvirik, 2018b, 2018c; Lesáková, 2016; Schooler, 1971; Sharma et al., 1995), age (Caruana \& Magri, 1996; Čvirik, 2018a, 2018b, 2018c; Grundey \& Bakowska, 2008; Klein \& Ettensoe, 1999; Lesáková, 2016; Schooler, 1971; Shimp \& Sharma, 1987) and region (Čvirik, 2018c). Therefore, we have chosen a quota sample to maintain these demographic variables from the basic population.

The first stage was to determine quotas in the basic population (see Table 1). Quotas for research were age, gender and residence (region). The second stage was to apply quotas to create the sample (based on judgement sample and random sampling — random walk method, where the researcher addressed respondents according to critical factors and randomly found respondents who matched the target group's characteristics). The basis for our research was 628 respondents. 
Table 1 | Quotas and their application

\begin{tabular}{c|lcc}
\hline Factors & & Quotas [\%] & Quotas applied [pcs.] \\
\hline \multirow{2}{*}{ Gender } & Men & 48.8 & 306 \\
& Women & 51.2 & 322 \\
\hline \multirow{3}{*}{ Age } & 15-39 years old & 40.31 & 252 \\
& 40-64 years old & 41.3 & 260 \\
& Older than 65 years & 18.39 & 116 \\
\hline \multirow{5}{*}{ Region } & Banskobystrický & 12.03 & 76 \\
& Bratislavský & 11.67 & 74 \\
& Košický & 14.68 & 92 \\
& Nitranský & 12.58 & 80 \\
& Prešovský & 15.12 & 94 \\
& Trenčianský & 10.87 & 68 \\
& Trnavský & 10.31 & 64 \\
& Žilinský & 12.72 & 80 \\
\hline$\Sigma$ & & $\mathbf{1 0 0}$ & $\mathbf{6 2 8}$ \\
\hline
\end{tabular}

Source: author's calculations based on SOSR (2020)

As shown in Table 1, the sample surveyed represents a representative sample of the population of Slovakia older than 15 years according to the following quotas: age, gender and residence (region). For a sample of 628 respondents, the maximum statistical error (with a $95 \%$ confidence probability) was around $4 \%$.

\subsection{The questionnaire}

We conducted a standardised inquiry conducted by a research tool - a questionnaire. The questionnaire was created in a print form and consisted of four parts:

The first part of the questionnaire was focused on measuring consumer ethnocentrism based on CETSCALE. CETSCALE, in its original form, contained seventeen statements that dealt with respondents' preferences of domestic and foreign products. The respondent replied to all statements with consent/disagreement, the intensity of which was spread across the seven-point Likert scale. According to the study Čvirik (2018a) conducted in Slovakia, we have concluded that the standard version of CETSCALE (Shimp \& Sharma, 1987) is not appropriate and needs to be updated. Therefore, we used a nine-item scale that, based on the study of Čvirik (2018a), achieved high validity and reliability (Cronbach's alpha 0.879). The modified CETSCALE used a five-point Likert scale ( 1 = strongly disagree, 5 = strongly agree). CETSCALE values would range from 9 (representing low consumer ethnocentrism) and 45 (representing intense consumer ethnocentrism).

The modified CETSCALE used by us achieved a high-reliability level (Cronbach's alpha = 0.888). The modified CETSCALE was used in the primary questionnaire survey as a tool for measuring ethnocentrism. The mean values, standard deviations and Cronbach's alpha for individual CETSCALE statements were recorded in Table 2. 


\begin{tabular}{|c|c|c|c|}
\hline CETSCALE items* & $\begin{array}{l}\text { Mean } \\
\text { scores }\end{array}$ & $\begin{array}{l}\text { Standard } \\
\text { deviations }\end{array}$ & $\begin{array}{l}\text { Cronbach's } \\
\text { alpha** }\end{array}$ \\
\hline $\begin{array}{l}\text { 1. Only those products should be imported that are } \\
\text { unavailable in the Slovak Republic. }\end{array}$ & 3.38 & 1.44 & 0.876 \\
\hline Slovak products, first, last, and foremost. & 3.00 & 1.48 & 0.885 \\
\hline $\begin{array}{l}\text { 3. Purchasing foreign-made products is un- } \\
\text { Slovakian. }\end{array}$ & 2.39 & 1.15 & 0.887 \\
\hline $\begin{array}{l}\text { 4. It is not right to purchase foreign products, } \\
\text { because it puts the Slovaks out of jobs. }\end{array}$ & 2.80 & 1.22 & 0.880 \\
\hline $\begin{array}{l}\text { 5. A real Slovak should always buy Slovak - made } \\
\text { products. }\end{array}$ & 2.57 & 1.35 & 0.885 \\
\hline $\begin{array}{l}\text { 6. We should purchase products manufactured in } \\
\text { Slovak Republic instead of letting other countries } \\
\text { get rich off us. }\end{array}$ & 3.28 & 1.59 & 0.875 \\
\hline $\begin{array}{l}\text { 7. The Slovaks should not buy foreign products, } \\
\text { because this hurts Slovak business and causes } \\
\text { unemployment. }\end{array}$ & 2.84 & 1.36 & 0.876 \\
\hline $\begin{array}{l}\text { 8. We should buy from foreign countries only those } \\
\text { products that we cannot obtain within our own } \\
\text { country. }\end{array}$ & 2.77 & 1.45 & 0.881 \\
\hline $\begin{array}{l}\text { 9. Slovak consumers who purchase products made } \\
\text { in other countries are responsible for putting their } \\
\text { fellow Slovaks out of work. }\end{array}$ & 2.50 & 1.14 & 0.880 \\
\hline
\end{tabular}

Source: author's calculations

Notes: * Based on Shimp and Sharma (1987) and Čvirik (2018a). ${ }^{* *}$ Overall Cronbach's alpha $=0.888$.

The second part of the questionnaire was focused on measuring patriotism. The measure of patriotism was carried out based on the Pseudo-patriotic scale (Adorno et al., 1950). The author of the scale named it with the prefix 'pseudo' because, based on his conviction, he claimed that this had been only an external manifestation of patriotism and not a genuine internal belief that could not be measured correctly. In the original, the scale contained fourteen statements to which the respondent replied with consent/disagreement, the intensity of which was spread over a five-degree Likert scale. It is necessary to realise that the scale was created at the turn of the 40 s -50 s and, therefore, a post-war period.

For this reason, some statements were outdated and needed to be modified or excluded. Our modified scale contained nine statements. It was also necessary to identify a related country that, at the same time, could be understood as a competitive country in terms of frequent comparisons in various economic-social identifiers. In our case, the Czech Republic and Hungary seemed to be the best option but based on the common history of the Czech Republic and Slovakia; we have chosen the Czech Republic. The respondent replied to all statements with agreement/disagreement, the intensity of which is spread across the 5-point Likert scale ( 1 = strongly disagree, $5=$ strongly agree). Based on the above mentioned, it can be stated that pseudo-patriotism scale values would be in the range of $9-45$ points, with 9 representing low patriotism and 45 points representing strong patriotism. The modified Pseudopatriotism scale used by us achieved an adequate level of reliability (Cronbach's 
alpha $=0.721)$. The modified scale was used in the primary questionnaire survey as a tool for measuring patriotism. Mean values, standard deviations and Cronbach's alpha for individual statements were recorded in Table 3.

Table 3 | Modified Pseudopatriotism scale

\begin{tabular}{|c|c|c|c|}
\hline Pseudopatriotism scale items ${ }^{\star}$ & $\begin{array}{l}\text { Mean } \\
\text { scores }\end{array}$ & $\begin{array}{l}\text { Standard } \\
\text { deviations }\end{array}$ & $\begin{array}{l}\text { Cronbach's } \\
\text { alpha** }\end{array}$ \\
\hline $\begin{array}{l}\text { 1. Patriotism and loyalty to the country are the first } \\
\text { and most important requirements of a good } \\
\text { citizen. }\end{array}$ & 2.70 & 0.92 & 0.698 \\
\hline $\begin{array}{l}\text { 2. Some forms of military training, obedience, and } \\
\text { discipline such as drill, marching, and simple } \\
\text { commands should be part of the elementary } \\
\text { school educational programme. }\end{array}$ & 1.98 & 0.54 & 0.713 \\
\hline $\begin{array}{l}\text { 3. Under our judicial system, the punishment } \\
\text { awarded to those who disobey the law of the land } \\
\text { is very light. }\end{array}$ & 1.93 & 0.25 & 0.720 \\
\hline $\begin{array}{l}\text { 4. Czech can never advance to level of Slovaks due } \\
\text { mainly to the innate laziness, lack of ambition, and } \\
\text { general backwardness of the Czech. }\end{array}$ & 2.70 & 0.77 & 0.689 \\
\hline $\begin{array}{l}\text { 5. The main threat to basic Slovak institutions comes } \\
\text { from the infiltration of foreign ideas, doctrines, } \\
\text { and media. }\end{array}$ & 2.43 & 0.88 & 0.679 \\
\hline Slovakia should teach honesty to other countries. & 2.25 & 0.80 & 0.686 \\
\hline $\begin{array}{l}\text { 7. Only natural Slovak citizens should have the right } \\
\text { to hold office under the Constitution of Slovakia. }\end{array}$ & 2.55 & 0.82 & 0.699 \\
\hline $\begin{array}{l}\text { 8. It is a great mistake to allow refugees from other } \\
\text { countries to enter Slovakia. }\end{array}$ & 3.11 & 1.37 & 0.720 \\
\hline $\begin{array}{l}\text { 9. When international matches are played in } \\
\text { Slovakia, the audience should not be allowed to } \\
\text { wave flags of other countries. }\end{array}$ & 2.61 & 0.96 & 0.707 \\
\hline
\end{tabular}

Source: author's calculations

Notes: ${ }^{*}$ Based on Adorno et al. (1950). ${ }^{* *}$ Overall Cronbach's alpha $=0.721$.

Since they were modified measuring tools, it was necessary to verify their reliability. Cronbach's alpha is used to investigate the reliability (accuracy and reliability of a research tool) within the internal consistency of the selected scale (Tavakol \& Dennick, 2011). As we can see in Table 2, the total value of Cronbach's alpha value for modified CETSCALE is 0.888 , which can be interpreted as a high value. We can see in Table 3 that Cronbach's alpha value for the modified Pseudopatriotism scale is 0.721 , which can be interpreted as a good value. From a practical point of view, it should also be stated that if the Cronbach's alpha value for the individual statements is higher than a total value, it is advisable to exclude this statement in future researches. It will increase the overall accuracy and reliability of the research tool - in our case CETSCALE. As we can see, it is not appropriate to rule out any of the statements. The mean's standard deviation represents the calculated arithmetic mean dispersion across the different samples selected from one main population. The standard deviation shows to what extent the individual measured values are around the mean value. The smaller the standard deviation, the closer the measured values are around the mean 
value. If the variance is smaller, it can be understood that the statement was rated similarly by all respondents. As we can see, respondents' answers were more consistent on the Pseudopatriotism scale.

The third part of the questionnaire focused on examining consumers' attitudes toward domestic products. We examined the overall assessment but also the attitudes of consumers to selected product categories. The investigated statements for single product categories were recorded in Table 4.

Table 4 | Examined statements of attitudes towards domestic product categories

\begin{tabular}{|c|c|c|c|c|c|c|c|}
\hline \multicolumn{2}{|r|}{ Statements $\quad \begin{array}{r}\text { Product } \\
\text { category }\end{array}$} & DP & MP & $\mathrm{VaF}$ & C & $\mathbf{E}$ & A \\
\hline 1. & $\begin{array}{l}\text { Slovak products have better quality than } \\
\text { imported products. }\end{array}$ & $x$ & $x$ & $x$ & $x$ & $x$ & $x$ \\
\hline 2 & $\begin{array}{l}\text { Slovak products have a better composition } \\
\text { than foreign products. }\end{array}$ & $x$ & $x$ & $x$ & 0 & 0 & 0 \\
\hline 3. & $\begin{array}{l}\text { Slovak products have a better taste than } \\
\text { foreign products. }\end{array}$ & $x$ & $x$ & $x$ & 0 & 0 & 0 \\
\hline 4. & $\begin{array}{l}\text { Slovak products are cheaper than foreign } \\
\text { products. }\end{array}$ & $x$ & $x$ & $x$ & $x$ & $x$ & $x$ \\
\hline 5. & $\begin{array}{l}\text { Whenever possible, I buy products made in } \\
\text { Slovakia. }\end{array}$ & $x$ & $x$ & $x$ & $x$ & $x$ & $x$ \\
\hline 6. & $\begin{array}{l}\text { If the Slovak equivalent of the product is } \\
\text { available for the same price as the foreign } \\
\text { one, I prefer it. }\end{array}$ & $x$ & $x$ & $x$ & $x$ & $x$ & $x$ \\
\hline \multicolumn{2}{|r|}{ Maximum possible number of points } & 30 & 30 & 30 & 20 & 20 & 20 \\
\hline \multicolumn{2}{|r|}{ Minimum possible number of points } & 5 & 5 & 5 & 5 & 5 & 5 \\
\hline \multicolumn{2}{|c|}{ Average of scale } & 17.5 & 17.5 & 17.5 & 12.5 & 12.5 & 12.5 \\
\hline
\end{tabular}

Source: author's calculations

Notes: $x$ - will be examined, 0 - will not be examined, DP - Dairy products, MP - Meat products, VaF Vegetables and Fruits, C - Clothing, E - Electronics and A - Automobile.

Statements followed the main features of the product categories and the two basic decision factors - price and quality. The first three statements focused on assessing the quality of domestic and/or foreign product categories. The first examining quality in general, the second was focusing on composition and the third on taste. The fourth statement examined the comparison between domestic and foreign products prices. The fifth statement examined the purchase intent (determination to buy Slovak products). The sixth statement examined the purchase intent of domestic (or foreign) products, assuming the elimination of the price factor. Statements were set positively towards domestic products, meaning that the higher the rate will be measured, the more consumers are more inclined towards domestic products.

The last part of the questionnaire was devoted to thanking respondents and possible comments of responders.

\section{Results}

In the primary research, we used a quantitative method to collect data. We conducted a standardised query using a research tool - the questionnaire. 628 respondents attended the 
research. All respondents come from Slovakia. To achieve the primary goal, we focused on solving partial goals, based on which we formulated hypotheses and research questions. In the next section, we focus on answering research questions and verifying hypotheses.

RQ1: What is the consumer ethnocentrism level in Slovakia?

The average consumer ethnocentrism investigated accounted for 25.54 points below the average in scale (scale average $-27 ;\langle 9,45\rangle$ scale). The average calculation error is 0.47 points. The lowest measured consumer ethnocentrism rate has reached 9 points, which is the smallest possible measurable value. The modus represents a value of 32 points and a median of 28 points. Overall, we rate consumer ethnocentrism in Slovakia as below-average.

RQ2: What is the patriotism level in Slovakia?

The average of patriotism investigated accounted for 22.26 points below the average in scale (scale average $-27 ;<9,45>$ scale). The average calculation error is 0.23 points. The lowest measured rate of patriotism has reached 10 points, and the maximum was 31 points. The modus represents a value of 25 points and a median of 23 points. Overall, we rate the patriotism in Slovakia as below-average.

$\mathrm{H} 1$ : There is a relationship between consumer ethnocentrism and patriotism.

To confirm (refute) the hypotheses, we chose the ANOVA one-way test. Based on the test, it can be stated that the F-value (38.935) > F crit. value (3.856) hypothesis can be confirmed. Confirmation of the hypothesis is also supported by the fact that Alpha $(0.05)>\mathrm{P}$-value (0.000). In this way, it can be rejected that it was just a noise. We confirm that there is a relationship between the cognitive component and the conative component.

RQ3: What is the direction and magnitude of patriotism impact on consumer ethnocentrism?

We used regression analysis to determine the direction and magnitude of this relationship (see Table 5).

Table 5 | Regression analysis of the relationship between consumer ethnocentrism and patriotism

\begin{tabular}{|c|c|c|}
\hline & & Patriotism and consumer ethnocentrism \\
\hline \multirow{3}{*}{ Regression Statistics } & Multiple R & 0.830 \\
\hline & R Square & 0.688 \\
\hline & Standard Error & 4.69 \\
\hline \multirow{3}{*}{ ANOVA } & Alpha & 0.05 \\
\hline & P-value & 0.000 \\
\hline & Significance $\mathbf{F}$ & 0.000 \\
\hline \multicolumn{2}{|c|}{ Regression function } & positive \\
\hline
\end{tabular}

Source: author's calculations

The regression analysis output consists of two parts: the first part is the correlation analysis output. The second is the ANOVA output, where we test the suitability of the model used. We can see a positive relationship between consumer ethnocentrism and patriotism. In ANOVA, we test a null hypothesis that claims the model we have chosen to explain dependence (in our case, linear regression line) is not appropriate (the alternative hypothesis argues the 
opposite). The F-test is used to evaluate this claim. The significance $F \leq 0.05$ ( $\alpha$ - significance level) means that the model has been selected correctly. The null hypotheses tested in this analysis relate to the significance of the locating constant and the regression coefficient, with the null hypothesis asserting the insignificance of the relevant coefficient and the alternative hypothesis of its significance. The $\mathrm{P}$-value ( $\mathrm{P}$-value) serve to evaluate these claims. The $\mathrm{P}$ value for the locating constant is less than 0.05 (alpha). This suggests that the locating constant is statistically significant. As can be seen, the Multiple R (correlation coefficient) is 0.830 , which means a high degree of interdependence. The value of $R$ Square is the value of the determination coefficient - in our case, 0.687 . This value tells us that the regression line explains the variability of variables to about $68.7 \%$, and $31.3 \%$ represents unexplained variability (influence of random variables, noise). The standard error is 4.69 which is acceptable given the depth of the measurement tools.

RQ4: How do Slovak consumers evaluate selected domestic product category?

In this article, we focus on selected product categories: dairy product, meat products, vegetables and fruits, clothing, electronics and automobile. The average measured values were recorded in Table 6.

Table 6 | Evaluation of domestic products

\begin{tabular}{l|c|c|c|c|c|c}
\hline \multicolumn{1}{c|}{ Statements } & DP & MP & VaF & C & E & A \\
\hline $\begin{array}{l}\text { Slovak products are of better quality } \\
\text { than imported products. }\end{array}$ & 4.14 & 3.95 & 3.15 & 3.15 & 2.41 & 2.55 \\
$\begin{array}{l}\text { Slovak products have a better } \\
\text { composition than foreign products. }\end{array}$ & 3.21 & 3.10 & 2.78 & $\mathrm{x}$ & $\mathrm{x}$ & $\mathrm{x}$ \\
$\begin{array}{l}\text { Slovak products have a better taste } \\
\text { than foreign products. }\end{array}$ & 3.09 & 2.39 & 2.84 & $\mathrm{x}$ & $\mathrm{x}$ & $\mathrm{x}$ \\
$\begin{array}{l}\text { Slovak products are cheaper than } \\
\text { foreign products. }\end{array}$ & 1.95 & 1.74 & 2.17 & 1.45 & 1.65 & 1.59 \\
$\begin{array}{l}\text { Whenever possible, I buy products } \\
\text { made in Slovakia. }\end{array}$ & 2.32 & 2.84 & 2.74 & 2.03 & 1.95 & 2.84 \\
$\begin{array}{l}\text { If the Slovak equivalent of the product } \\
\text { is available for the same price as the } \\
\text { foreign one, I prefer it. }\end{array}$ & 3.89 & 3.01 & 2.55 & 3.82 & 2.63 & 2.18 \\
\hline Range & $<5,30>$ & $<5,30>$ & $<5,30>$ & $<5,20>$ & $<5,20>$ & $<5,20>$ \\
\hline \begin{tabular}{l} 
Mean score \\
\hline
\end{tabular} & 22,05 & 19,80 & 18,39 & 10,21 & 8,46 & 9,67 \\
\hline
\end{tabular}

Source: author's calculations

Notes: $\mathrm{x}$ - is not examined, DP - Dairy products, MP - Meat products, VaF - Vegetables and Fruits, C - Clothing, E - Electronics and A - Automobile.

As we can see in Table 6 the best rating is achieved by dairy products. Meat products and vegetables, and fruits are equally highly rated product categories. Of non-food products, the best-rated category is clothing. Electronics and automotive results are below average. From the point of view of the examined items, it can be stated that consumers evaluate selected product categories of food character as significantly better than foreign ones. The same applies to the product category of clothing. Consumers assess electronics and automotive on average and below-average against foreigners. Consumers evaluate very favourably the composition of mainly dairy products against foreigners. Milk products most suited to taste. Meat and vegetables, and fruits reach below-average levels against foreigners. Consumers 
consider all selected product categories to be more costly to foreigners, which they see as cheaper in their perception. However, if the price of domestic and foreign products is at the same level, consumers prefer domestic equivalence, especially for dairy and meat products and clothing.

H2: Consumers with higher consumer ethnocentrism levels have a more positive attitude towards domestic products (product category research).

To refute the hypotheses, we chose the ANOVA one-way test. Based on the test, it can be stated that the F-value > F crit. value, the hypothesis can be confirmed (in all cases). Confirmation of the hypothesis is also supported by the fact that alpha (0.05) > P-value. In this way, it can be rejected; it was just a noise. We confirm a relationship between the rate of consumer ethnocentrism and the evaluation of selected product categories. We used regression analysis to determine the direction and magnitude of this relationship (see Table 7).

Table 7 | Results of regression analysis

\begin{tabular}{c|c|c|c|c|c|c|c}
\hline \multicolumn{2}{c|}{} & DP & MP & VaF & C & E & A \\
\hline \multirow{2}{*}{$\begin{array}{c}\text { Regression } \\
\text { Statistics }\end{array}$} & Multiple R & 0.887 & 0.624 & 0.562 & 0.839 & 0.041 & 0.439 \\
& R Square & 0.786 & 0.390 & 0.316 & 0.704 & 0.002 & 0.193 \\
& Standard Error & 2.555 & 4.107 & 3.875 & 1.975 & 2.544 & 2.898 \\
\hline \multirow{3}{*}{ ANOVA } & Alpha & 0.05 & 0.05 & 0.05 & 0.05 & 0.05 & 0.05 \\
& P-value & 0.000 & 0.000 & 0.000 & 0.009 & 0.000 & 0.000 \\
& Significance F & 0.000 & 0.000 & 0.000 & 0.000 & 0.037 & 0.000 \\
\hline \multicolumn{2}{c}{ Regression function } & positive & positive & positive & positive & positive & positive \\
\hline
\end{tabular}

Source: author's calculations

Notes: DP - Dairy products, MP - Meat products, VaF - Vegetables and Fruits, C - Clothing, E Electronics and A - Automobile.

We can see a positive relationship between consumer ethnocentrism and the evaluation of domestic products in all product categories. In ANOVA, we test a null hypothesis that claims the model we chose to be explaining dependence (in our case, linear regression line) is not appropriate (the alternative hypothesis argues the opposite). The F test is used to evaluate this claim. Significance $F \leq 0.05$ ( $\alpha$ - significance level) means that the model has been selected correctly. The null hypotheses tested in this analysis relate to the significance of locating constant and regression coefficient, with the null hypothesis asserting the insignificance of the relevant coefficient and the alternative hypothesis of its significance. Pvalues serve to evaluate these claims. In all products categories, the P-value for the locating constant is less than $0.05(\alpha)$. This suggests that the locating constant is statistically significant. As can be seen, three strong dependencies were found in this research: dairy products - the selected regression line explains revenue variability to approximately $78.6 \%$; meat products - the selected regression line explains revenue variability to approximately $39 \%$; clothing - the selected regression line explains revenue variability to approximately $70.4 \%$. Fruits and vegetables and automobiles show an average dependence on the results of consumer ethnocentrism. A weak (almost zero) thoughtfulness was found in electronics. 
H3: Consumers with higher levels of patriotism have a more positive attitude towards domestic products.

To confirm (refuse) the hypotheses, we chose the ANOVA one-way test. Based on the test, it can be stated that the F-value $>\mathrm{F}$ crit. value, the hypothesis can be confirmed (in all cases). Confirmation of the hypothesis is also supported by the fact that alpha $(0.05)>P$-value. In this way, it can be rejected that it was just a noise. We confirm that there is a relationship between the rate of patriotism and the evaluation of selected product categories. We used regression analysis to determine the direction and magnitude of this relationship (see Table 8).

Table 8 | Results of regression analysis

\begin{tabular}{c|c|c|c|c|c|c|c}
\hline \multicolumn{2}{c|}{} & DP & MP & VaF & C & E & A \\
\hline \multirow{2}{*}{$\begin{array}{c}\text { Regression } \\
\text { Statistics }\end{array}$} & Multiple R & 0.781 & 0.693 & 0.534 & 0.708 & 0.565 & 0.658 \\
& R Square & 0.609 & 0.480 & 0.285 & 0.501 & 0.320 & 0.432 \\
& Standard Error & 2.545 & 2.937 & 3.44 & 2.877 & 3.36 & 3.068 \\
\hline \multirow{3}{*}{ ANOVA } & Alpha & 0.05 & 0.05 & 0.05 & 0.05 & 0.05 & 0.05 \\
& P-value & 0.000 & 0.000 & 0.000 & 0.000 & 0.000 & 0.000 \\
& Significance F & 0.000 & 0.000 & 0.000 & 0.000 & 0.005 & 0.000 \\
\hline \multicolumn{2}{r}{ Regression function } & positive & positive & positive & positive & positive & positive \\
\hline
\end{tabular}

Source: author's calculations

Notes: DP - Dairy products, MP - Meat products, VaF - Vegetables and Fruits, C - Clothing, E Electronics and A - Automobile.

We can see a positive relationship between patriotism and the evaluation of domestic products in all product categories. In ANOVA, we test a null hypothesis that claims the model we have chosen to explain dependence (in our case, linear regression line) is not appropriate (the alternative hypothesis argues the opposite). The $F$ test is used to evaluate this claim. The significance $F \leq 0.05$ ( $\alpha$ - significance level) means that the model has been selected correctly. The null hypotheses tested in this analysis relate to the significance of the locating constant and the regression coefficient, with the null hypothesis asserting the insignificance of the relevant coefficient and the alternative hypothesis of its significance. The P-value for the locating constant is less than 0.05 (alpha) in all product categories. This suggests that the locating constant is statistically significant. As can be seen, three strong dependencies were found: dairy products - the selected regression line explains revenue variability to approximately $60.9 \%$; meat products - the selected regression line explains revenue variability to approximately $48 \%$; vegetables and fruits - the selected regression line explains revenue variability to approximately $28.5 \%$; clothing — the selected regression line explains revenue variability to approximately $50.1 \%$, electronics - the selected regression line explains revenue variability to approximately $32 \%$ and automobile - the selected regression line explains revenue variability to approximately $43.2 \%$. Thus, Slovaks, who have a higher patriotism rate, evaluate Slovak products more positively than foreign ones.

\section{Discussion}

The results of the quantitative survey show low rates of consumer ethnocentrism and patriotism in Slovakia. Slovak consumers do not perceive foreign products as 'enemies of the 
domestic economy', reflected in a low level of consumer ethnocentrism. Some other studies have also declared a low level of consumer ethnocentrism in Slovakia (Čvirik 2018a, 2018b, 2018c). Based on the results of domestic production preferences only in specific product categories, it can be assumed that this is an effect of the country of origin and not ethnocentrism. The country of origin's effect is related to the country (domestic or foreign) and the product (or product category). It is still based on factors (such as tradition, quality, sensory properties of products) and not based on the domestic economy's protection and prosperity (Čvirik, 2019). The low level of patriotism can be said to be due to distrust in government institutions. Still, the elements of patriotism can be seen mainly in protecting the country against refugees. We have shown a positive link between the concept of patriotism and consumer ethnocentrism. Patriotism is also the basis of consumer ethnocentrism (Shimp \& Sharma, 1987).

Dairy products were best judged by Slovak consumers, which confirms the theory that this is a country-of-origin effect rather than an ethnocentrism effect (dairy products have a tradition in Slovakia and are known for their quality). In examining the interconnection of selected product categories and consumer ethnocentrism, we have shown a positive interconnection in all categories. Still, only dairy products, meat products, clothing and vegetables and fruits can be considered significant. When linking patriotism and evaluating selected product categories, we found a link in all the selected categories (Dairy products, Meat products, Vegetables and Fruits, Clothing, Electronics and Automobile). In all cases, it was a positive relationship of these variables, as part of the country-of-origin-effect, as suggested by other studies (Kotabe \& Helsen, 2010). Patriotism has a more generalised impact and thus affects the rating of several product categories.

\section{Conclusions}

The primary survey supports this presented study. We used the non-random sample (Quota sample) based on a judgment sample and random sampling. In general, we can state that a sample was not so ethnocentrically consumer and reached low patriotism value.

An analysis of the concept of consumer ethnocentrism and systematisation of the theory of consumer ethnocentrism in terms of demographic factors can be considered as a theoretical contribution. The primary survey results can also be cleaned up at the theoretical level, thus enriching the knowledge base of the issue.

Based on knowledge, we can state that consumer ethnocentrism and patriotism have similar and different features. The agreement is found in effects creating these concepts - the positive evaluation effect and domestic products' preferences against foreign ones in different product categories. The cause of these effects is a significant difference. Consumer ethnocentrism focuses more on economic aspects of home country support while patriotism has a broader character. The survey results prove a strong connection between these two concepts. Both concepts have a positive effect on domestic product evaluation. The effect's intensity influencing consumer behaviour changes from products point of view. The consumer ethnocentrism impact and patriotism impact mostly show in product categories of dairy products and clothes. Based on the results, we can state that patriotism showed in all research categories (Multiple $R>0.5$ ). At the same time, consumer ethnocentrism did not impact the evaluation and preferences of domestic products in product categories, e.g. electronics and automotive (Multiple R $>0.5$ ). 
The research of other product categories would be suitable in the future. Moreover, research in different countries would be suitable to compare results on an international level. In the future, it would be appropriate to examine the impact of patriotism and consumer ethnocentrism on the assessment and perception of domestic and foreign brands. It would also be appropriate to investigate in the context of the country of origin effect. The study also has limits. The study focuses only on selected product categories. The sample was selected based on the quota method, with only three demographic factors selected as quotas.

\section{References}

Adorno, T. W., Frenkel-Brunswik, E., Levinson, D., \& Sanford, N. (1950). The authoritarian personality. New York: Harper \& Row Publishers.

Alam, S. S., Ahmad, A., Ahmad M.S., \& Nik Hashim, N.M.H. (2011). An empirical study of an extended theory of planned behaviour model for pirated software purchase. World Journal of Management, 3(1), 124-133.

Albarq, A., \& Nik Mat, N. K. (2007). Antecedents of consumer ethnocentrism [Conference proceedings]. Australian and New Zealand Marketing Academy (ANZMAC) Conference (3-5 December), University of Otago, Dunedin, New Zealand.

Badzińska, E. (2011). Konkurowanie przedsiębiorstw w segmencie młodych konsumentów. Warszawa: Polskie Wydawnictwo Ekonomiczne.

Balabanis, G., \& Siamagka, N.-T. (2017). Inconsistencies in the behavioural effects of consumer ethnocentrism: The role of brand, product category and country of origin. International Marketing Review, 34(2), 166-182. https://doi.org/10.1108/IMR-03-2015-0057

Balabanis, G., Diamantopoulos, A., Mueller, R. D., \& Melewar, T.C. (2001). The impact of nationalism, patriotism and internationalism on consumer ethnocentric tendencies. Journal of International Business Studies, 32(1), 157-175. https://doi.org/10.1057/palgrave.jibs.8490943

Brengman, M. (2002). The impact of colour in the store environment: An environmental psychology approach [Dissertation thesis]. University of Ghent.

Bruning, E. (1997). Country of origin, national loyalty and product choice: Case of international air travel. International Marketing Review, 14(1), 59-74. https://doi.org/10.1108/02651339710159215

Caruana, A., \& Magri, E. (1996). The effects of dogmatism and social class variables on consumer ethnocentrism in Malta. Marketing Intelligence \& Planning, 14(4), 39-44. https://doi.org/10.1108/02634509610121569

Čvirik, M. (2018a). Spotrebitel'ský etnocentrizmus v generačnom kontexte. Studia commercialia Bratislavensia, Scientific Journal of Faculty of Commerce, 11(1), 5-14.

Čvirik, M. (2018b). Spotrebitel'ský etnocentrizmus na Slovensku. Vedecké state Obchodnej fakulty, 1(1), 5-13.

Čvirik, M. (2018c). Spotrebitel'ský etnocentrizmus - skúmanie diferencií na základe deskriptívnych charakteristík spotrebitela. In M. Helísek (Ed.). Ekonomický výzkum - prezentace výsledků doktorandů (pp. 29-39). Praha: Nakladatelství Vysoké školy finanční a správní.

Čvirik, M. (2019). Rola krajiny pôvodu vo vybraných problémoch marketingu. Ekonomika cestovného ruchu a podnikanie, 11(2), 16-24.

Ding, Q. S. (2017). Chinese products for Chinese people? Consumer ethnocentrism in China. International Journal of Retail \& Distribution Management, 45(5), 550-564. https://doi.org/10.1108/IJRDM-11-2016-0212 
Eagly, A. H., \& Chaiken, S. (1993). The psychology of attitudes. Fort Worth, TX: Harcourt Brace Jovanovich.

Grundey, D., \& Bakowska, S. (2008). Consumer economics: Brand awareness among Polish consumers. Transformations in Business \& Economics, 7(2), 186-199.

Han, C. M. (1988). The role of consumer patriotism in the choice of domestic versus foreign products. Journal of Advertising Research, 28(1), 25-32.

Ismail, Z., Masood, S., \& Tawab, Z. M. (2012). Factors affecting consumer preference of international brands over local brands. 2nd International Conference on Social Science and Humanity, 31(12), 54-59.

Khalid, N. R., Che Wel, C. A., Alam, S. S., \& Mokhtaruddin, S. A. (2018). The influence of self-congruity on purchase intention for cosmetic merchandises. International Journal of Academic Research in Business and Social Sciences, 8(4), 933-945. https://doi.org/10.6007/ijarbss/v8-i4/4122

Klein, J. G., \& Ettensoe, R. (1999). Consumer animosity and consumer ethnocentrism: An analysis of unique antecedents. Journal of International Consumer Marketing, 11(4), 5-24. https://doi.org/10.1300/J046v11n04_02

Kotabe, M., \& Helsen, K. (2010). Global marketing management (5th ed.). Hoboken, NJ: John Wiley \& Sons.

Lesáková, D. (2016). Ethnocentric behaviour in the Slovak population: Do Slovaks purchase Slovak dairy products? Ekonomický časopis, 64(8), 795-807.

Lieskovská, V., Megyesiová, S., \& Bilohuščinová, D. (2013). Akceptácia podpory predaja domácich produktov spotrebitel'mi v maloobchode SR. Marketing Science \& Inspirations, 8(2), 2-11.

Liu, F., Murphy, J., Li, J., \& Liu, X. (2006). English and Chinese? The role of consumer ethnocentrism and country of origin in Chinese attitudes towards store signs. Australasian Marketing Journal, 14(2), 5-16. https://doi.org/10.1016/S1441-3582(06)70057-X

Lutz, S., Talavera, O., \& Park, S. M. (2014). Effect of foreign presence in a transition economy, regional and industry wide investment and firm - Level exports in Ukrainian manufacturing. Emerging Markets Finance and Trade, 44(5), 82-98. https://doi.org/10.2753/REE1540-496X440506

Puncheva-Michelotti, P., McColl, R., Vocino, A., \& Michelotti, M. (2014). Corporate patriotism as a source of corporate reputation: A comparative multi-stakeholder approach. Journal of Strategic Marketing, 22(6), 471-493. https://doi.org/10.1080/0965254X.2014.885989

Rezvani, S., Dehkordi, G. J., Rahman, M. S., Fouladivanda, F., Habibi, M., \& Eghtebasi, S. (2012). A conceptual study on the country of origin effect on consumer purchase intention. Asian Social Science, 8(12), 205-215. https://doi.org/10.5539/ass.v8n12p205

Sedláková, J., Schade, G., Vogler, W., \& Kretter, A. (2007). Spotrebitel'ské správanie sa mladých slovenských konzumentov vplyv etnocentrizmu a pôvodu potravín. Acta Oeconomica et Informatica, 10(2), 45-48.

Sharma, S., Shimp, T. A., \& Shin, J. (1995). Consumer ethnocentrism: A test of antecedents and moderators. Academy of Marketing Science Journal, 23(1), 26-37. https://doi.org/10.2307/3151638

Shimp, A. T., \& Sharma, S. (1987). Consumer ethnocentrism: Construction and validation of the CETSCALE. Journal of Marketing Research, 24(3), 280-289. https://doi.org/10.1177/002224378702400304.

Schiffman, L. G., \& Kanuk, L. L. (2010). Consumer behavior (11th ed). New Jersey, NJ: Pearson Education. 
Schooler, R. D. (1971). Bias phenomena attendant to the marketing of foreign goods in the US. Journal of International Business Studies, 2(1), 71-81. https://doi.org/10.1057/palgrave.jibs.8490732.

Statistical Office of the Slovak Republic (SOSR). (2020). Obyvatel'stvo podla mie SOSR sta sčitania, pohl., postav. v domác., rodinn. stavu, ekonom.aktivity, miesta narod., štát. prísluš. a veku - HC1 [Data file]. Retrieved from http://datacube.statistics.sk/\#!/folder/sk/root.

Sumner, W. G. (1906). Folkway: A study of the sociological importance of usages, manners, customs, mores, and morals. Boston: Ginn and Company.

Sumner, W. G. (2007). Folkway: A study of the sociological importance of usages, manners, customs, mores, and morals. New York, NY: Cosimo Classics.

Supphellen, M., \& Grønhaug, K. (2003). Building foreign brand personalities in Russia: The moderating effect of consumer ethnocentrism. International Journal of Advertising - The Review of Marketing Communications, 22(2), 203-226. https://doi.org/10.1080/02650487.2003.11072849.

Tavakol, M., \& Dennick, R. (2011). Making sense of Cronbach's alpha. International Journal of Medical Education, 2(1), 53-55. https://doi.org/10.5116/ijme.4dfb.8dfd.

Wang, C. L., \& Chen, Z. X. (2004). Consumer ethnocentrism and willingness to buy domestic products in a developing country setting: Testing moderating effects. Journal of Consumer Marketing, 21(6), 391-400. https://doi.org/10.1108/07363760410558663.

The research paper passed the review process. | Received: March 6, 2020; Revised: April 23, 2019; Accepted: May 5, 2020; Pre-published online: December 28, 2020; Published in the regular issue: July 2, 2021. 